\title{
Effect of preharvest aminoethoxyvinylglycine (AVG) on fruit quality attributes 'Formosa' plum stored at ambient temperature
}

\author{
Jung-Geun Kwon ${ }^{1}$, Jingi Yoo ${ }^{1}$, Hye-Won Kwon ${ }^{1}$, Dae Hyun Kim ${ }^{1}$, Young-Je Cho ${ }^{2}$, \\ Hee-Young Jung ${ }^{3}$, In-Kyu Kang ${ }^{1 *}$ \\ ${ }^{1}$ Department of Horticultural Science, Kyungpook National University, Daegu 41566, Korea \\ ${ }^{2}$ School of Food Science \& Biotechnology, Kyungpook National University, Daegu 41566, Korea \\ ${ }^{3}$ School of Applied Biosciences, Kyungpook National University, Daegu 41566, Korea
}

\section{수확 전 aminoethoxyvinylglycine (AVG) 처리가 ‘포모사’ 자두 과실의 상온저장에 따른 과실품질에 미치는 영향}

\author{
권중근 $^{1} \cdot$ 유진기 $^{1} \cdot$ 권혜원 $^{1} \cdot$ 김대현 ${ }^{1} \cdot$ 조영제 $^{2} \cdot$ 정희영 ${ }^{3} \cdot$ 강인규 $^{1 *}$ \\ ${ }^{1}$ 경북대학교 원예과학과, ${ }^{2}$ 경북대학교 식품공학부, ${ }^{3}$ 경북대학교 응용생명과학부
}

\begin{abstract}
This study was carried out to investigate the effect of a preharvest treatment with aminoethoxyvinylglycine (AVG) on fruit quality during ambient temperature storage of 'Fomosa' plum (Prunus salicina). Flesh firmness of the control fruit during storage decreased to less than $2.00 \mathrm{~N}$ after 12 days of storage, but AVG treated fruits remained above $4.00 \mathrm{~N}$ after 20 days of storage. The amount of ethylene produced in the control fruit began to increase from 12 days after storage and rapidly increased to $90.0 \mu \mathrm{L} / \mathrm{kg} / \mathrm{h}$ after 20 days of storage. However, AVG treated fruits showed low ethylene production of $20.0 \mu \mathrm{L} / \mathrm{kg} / \mathrm{h}$ after 24 days of storage. The titratable acid (TA) of control fruit decreased from $1.15 \%$ at harvest to $0.87 \%$ at 20 days after storage, but AVG treated fruits remained high at 1.04-1.08\% after 24 days of storage. The redness $\left(a^{*}\right)$ of the fruit peel at harvest was not statistically significant but increased in the AVG treated fruits during storage. Therefore, pre-harvest AVG treatment in 'Formosa' plums was effective to maintain the quality of fruits by decreasing the ethylene production and maintaining flesh firmness and TA of fruit during ambient temperature storage.
\end{abstract}

Key words : ethylene, firmness, titratable acidity, SSC/TA ratio, storage

\section{서 론}

우리나라 10 대 과실 중 하나인 자두는 사과, 배, 복숭아, 포도, 감, 감귤 등과 함께 우리나라를 대표하는 과실로 그 재배면적은 2011년 5,724ha(생산량 : 40,636톤)에서 2017년 7,324ha(생산량 : 63,776 톤)로 꾸준히 증가하는 추세를 보이 고 있다. 경북지역의 경우 2017 년 기준 재배면적이 $6,208 \mathrm{ha}$

*Corresponding author. E-mail : kangik@knu.ac.kr Phone : 82-53-950-5727, Fax : 82-53-950-5722

Received 08 July 2019; Revised 08 October 2019; Accepted 28 October 2019.

Copyright (c) The Korean Society of Food Preservation. All rights reserved.
로 전국 재배면적의 $84.8 \%$ 를, 생산량은 56,209 톤으로 전국 생산량의 $89.5 \%$ 로서 대부분을 차지하고 있다(1).

국내에서 재배되고 있는 대표적인 자두 품종은 '대석조 생', '포모사', ‘추희' 등으로 이들 품종들 중 '포모사 (Formosa)' 자두는 수확기가 7월 중순, 과형은 방추형, 과중 은 $150 \mathrm{~g}$ 내외로 대과에 속하고, 가용성 고형물 함량은 13.5 ${ }^{\circ} \mathrm{Brix}$ 로 과즙이 풍부하며, 향과 식감이 우수하여 소비자에 게 기호도가 높은 품종이다. 그러나 '포모사' 자두는 보구력 이 약하여 유통기한이 짧은 단점이 있어 경제적 손실이 발생하고 있다.

과실의 수확후 품질 저하는 선별, 저장, 유통 과정중 발생 하고(2), 특히, 국내에서는 대부분 상온유통에 따른 과실연 화가 빠르게 진행되고 있는 실정이다. 자두는 호흡급등형 
과실로 분류되며(3) ‘로얄지’, ‘손골드' 자두 품종들에서 수 확후 과실 경도와 산 함량이 감소하면서 과실품질이 저하되 는 요인이 에틸렌의 작용으로 알려져 있다 $(4,5)$.

일반적으로 수확후 자두 과실의 저장기간을 늘리기 위하 여 저온저장이 이용되고 있으나(4) 이러한 저장방법은 Monilinia laxa에 의한 internal breakdown, gel breakdown, brown rot 등의 생리적 장해 발생을 초래한다는 단점이 있다 $(4,6,7)$. 따라서 재배기간 중 과실에 에틸렌 생합성을 억제하 는 기술 적용을 통하여 이러한 문제점을 해결할 필요성이 있다.

Aminoethoxyvinylglycine(AVG)는 1-aminocyclopropane1-carboxylic acid(ACC) synthase의 활성을 억제하는 역할로 (8) 과실에 적용시 에틸렌 발생량을 감소시킴으로서 과실의 경도 및 산 함량의 감소가 억제되어 저장력을 증진시키는 효과가 있는 것으로 알려져 있다(9-11). 이러한 효과로 사과 품종인 '쓰가루'(10), ‘홍옥'(11), '갈라'(12), '산사'(13), ‘데 리셔스'(14)에, 배 품종인 ‘풍수', '행수'(15), ‘원황'(16)에, 복숭아 품종인 ‘레드헤븐'(17,18)과 ‘장택백봉'(19) 복숭아 에서도 AVG 처리가 저장기간동안 과실의 경도를 높게 유 지시켜 과실의 저장성이 향상되었다고 보고되었다. 그러나 '포모사' 자두의 수확전 $\mathrm{AVG}$ 처리에 대한 연구는 없는 실정 이다.

따라서 본 연구는 ‘포모사' 자두에 에틸렌 생합성억제제 인 AVG를 수확 전에 처리하였을 때 수확 후 상온저장 시 과실품질 변화와 상온유통 한계기를 구명하고자하였다.

\section{재료 및 방법}

\section{실험 재료}

본 시험은 2016년 경상북도 영천시 화남면 금호리에 위 치한 자두농가에 재식되어 있는 '포모사'(10년생) 나무를 대상으로 수세가 안정된 나무에서 과실을 수확한 후 상처나 병반이 없는 건전한 과실을 분류하여 실험재료로 사용하 였다.

\section{AVG 처리 및 저장조건}

$\operatorname{AVG}\left(15 \%\right.$, 상품명 : ReTain ${ }^{\circledR}$ Valent BioScience, Illinois, USA) 처리는 $75 \mathrm{mg} / \mathrm{L}$ 의 농도로 수확 10 일전(7월 9일)과 5 일전(7월 14일)에 각각 1 회 수체살포하였으며, 과실의 수 확은 관행적인 수확적기인 2016년 7월 19일에 실시하였다. 과실 저장조건은 온도 $25 \pm 1^{\circ} \mathrm{C}$ 로 설정하였고, 저장기간은 24일 동안 실시하였다. 과실 특성조사는 수확시와 7월 23 일, 7월 27일, 7 월 31 일, 8 월 4일, 8 월 8 일, 8 월 12 일 등 4 일 간격으로 총 7 회에 걸쳐 실시하였다.

\section{과실품질 특성}

과실의 경도는 직경 $5 \mathrm{~mm}$ plunger를 장착한 Rheometer (Compac-100II, Sun Scientific Co., Tokyo, Japan)를 사용하 여 과실 적도면의 과피를 제거한 후 과실 당 3회 측정한 값을 평균하여 Newton( $\mathrm{N})$ 으로 나타내었다. 산 함량은 전위 차 적정기(DL-15, Mettler Toledo Co., Greifensee, Switzerland) 를 사용하여 과즙 $5 \mathrm{~mL}$ 를 $0.1 \mathrm{~N} \mathrm{NaOH}$ 로 적정 후 자두의 주요 유기산인 malic acid로 환산하였고, 가용성 고형물 함 량은 디지털당도계(PR-201a, Atago, Tokyo, Japan)를 이용 하여 측정하였다. 과피색은 색차계(CR-210, Minolta Co., Tokyo, Japan)를 이용하여 양광면 3 부위의 $L^{\star}, a^{\star}, b^{\star}$ 값을 측정하여 평균값으로 나타내었다.

\section{에틸렌 발생량}

에틸렌 발생량은 밀폐용기에 1 반복 당 4 개의 과실을 넣어 2시간 방치한 후 head space에서 $1 \mathrm{~mL}$ 의 gas 시료를 채취하여 $\mathrm{FID}$ (flame ionization detector)를 장착한 gas chromatography(GC2010, Shimadzu, Kyoto, Japan)로 분석 하였다. Gas chromatography의 분석 조건은 Porapak $\mathrm{Q}(80 / 1002$ m, Restek, Bellefonte, PA, USA) column을 이용 하여 injector temperature $100^{\circ} \mathrm{C}$, oven temperature $90^{\circ} \mathrm{C}$, detector temperature $200^{\circ} \mathrm{C}$ 로 설정하였으며, carrier gas는 $\mathrm{He}$ 을 사용하였고, flow rate는 분당 $25 \mathrm{~mL}$ 로 하였다.

\section{통계 분석}

조사별 3 반복(1반복 5 과)에 대한 결과의 통계분석은 SPSS 프로그램(IBM SPSS Statistics 20, SPSS Inc., New York, USA)을 이용하여 분석하였다. 모든 측정 결과는 평 균(mean)표표준오차(standard error, SE)를 구하였으며, 각 항목의 평균값 차이는 유의수준 $\mathrm{p}<0.05$ 에서 one-way ANOVA test를 이용하여 검증하였고, 과실 품질간의 유의 성은 Duncan's multiple range test를 실시하였다.

\section{결과 및 고찰}

\section{수확시 과실품질}

수확 전 $\mathrm{AVG}$ 처리가 ‘포모사' 자두의 수확시 과실품질에 미치는 영향을 보면 Table 1과 같다. 모든 처리구들에서 과중, 가용성 고형물 및 산 함량은 차이는 보이지 않았지만 과실의 경도와 에틸렌 발생량은 차이를 보였다. 과실의 경 도를 보면 무처리 과실은 $4.17 \mathrm{~N}$ 이었지만 수확 10 일전과 5 일전 $\mathrm{AVG}$ 처리 과실들은 각각 $6.30 \mathrm{~N}$ 과 $6.29 \mathrm{~N}$ 으로 무처 리 과실에 비하여 높은 경도를 보였다. 그리고 에틸렌 발생 량 역시 무처리 과실은 $3.68 \mu \mathrm{L} / \mathrm{kg} / \mathrm{h}$ 이었지만 AVG 처리 과실들에서는 1.23 과 $1.32 \mu \mathrm{L} / \mathrm{kg} / \mathrm{h}$ 로 무처리 과실에 비하여 낮은 에틸렌 발생량을 보였다. 또한 과피색의 변화는 통계 
Table 1. Effects of AVG treatments on fruit quality attributes of 'Formosa' plums at harvest

\begin{tabular}{|c|c|c|c|c|c|}
\hline $\begin{array}{l}\text { Treatment } \\
(\mathrm{mL} / \mathrm{L})\end{array}$ & $\begin{array}{l}\text { Application time } \\
\left(\mathrm{DBH}^{1 /}\right)\end{array}$ & $\begin{array}{l}\text { Fruit weight } \\
\text { (g) }\end{array}$ & $\begin{array}{l}\text { Flesh firmness } \\
(\mathrm{N} / \Phi 11 \mathrm{~mm})\end{array}$ & $\begin{array}{l}\text { Soluble solids content } \\
\left({ }^{\circ} \text { Brix }\right)\end{array}$ & $\begin{array}{c}\text { Titratable acidity } \\
(\%)\end{array}$ \\
\hline Control & - & $109.9 \pm 4.93^{2) \mathrm{a} 3)}$ & $4.17 \pm 0.33^{b}$ & $7.93 \pm 0.06^{\mathrm{a}}$ & $1.15 \pm 0.01^{\mathrm{a}}$ \\
\hline \multirow[t]{4}{*}{ AVG (75) } & 10 & $115.6 \pm 5.61^{\mathrm{a}}$ & $6.30 \pm 0.25^{\mathrm{a}}$ & $8.43 \pm 0.26^{\mathrm{a}}$ & $1.16 \pm 0.01^{\mathrm{a}}$ \\
\hline & 5 & $116.6 \pm 5.62^{\mathrm{a}}$ & $6.29 \pm 0.63^{\mathrm{a}}$ & $8.63 \pm 0.43^{\mathrm{a}}$ & $1.15 \pm 0.02^{\mathrm{a}}$ \\
\hline & & \multirow{2}{*}{$\begin{array}{l}\text { Ethylene production } \\
(\mu \mathrm{L} / \mathrm{kg} / \mathrm{h})\end{array}$} & \multicolumn{3}{|c|}{ Fruit peel color } \\
\hline & & & $\begin{array}{l}\text { Lightness } \\
\left(\mathrm{L}^{*}\right)\end{array}$ & $\begin{array}{c}\text { Redness } \\
\left(\mathrm{a}^{*}\right)\end{array}$ & $\begin{array}{l}\text { Yellowness } \\
\left(\mathrm{b}^{*}\right)\end{array}$ \\
\hline Control & - & $3.68 \pm 0.98^{\mathrm{a}}$ & $40.1 \pm 1.52^{\mathrm{a}}$ & $15.9 \pm 2.28^{\mathrm{a}}$ & $12.9 \pm 1.14^{\mathrm{a}}$ \\
\hline \multirow[t]{2}{*}{ AVG (75) } & 10 & $1.32 \pm 0.67^{b}$ & $37.8 \pm 1.87^{\mathrm{a}}$ & $12.6 \pm 1.80^{\mathrm{a}}$ & $14.0 \pm 0.83^{\mathrm{a}}$ \\
\hline & 5 & $1.23 \pm 0.63^{\mathrm{b}}$ & $41.6 \pm 1.71^{\mathrm{a}}$ & $12.8 \pm 1.65^{\mathrm{a}}$ & $15.5 \pm 1.15^{\mathrm{a}}$ \\
\hline
\end{tabular}

${ }^{11}$ DBH: days before harvest date, which was 19 July 2016.

${ }^{2)}$ All value are expressed as mean $\pm \mathrm{SE}$ of triplicate determinations.

${ }^{3)}$ Different superscripts within the column are significantly different at $p<0.05$ by Duncan's multiple range test.

적 유의성은 보이지 않았으나 적색도 $\left(\mathrm{a}^{\star}\right)$ 의 경우 $\mathrm{AVG}$ 처리 과실에서 착색이 다소 지연되는 경향을 보였다. 이러한 결 과는 $\mathrm{AVG}$ 는 $\mathrm{ACC}$ synthase의 활성을 억제함으로서 과실에 적용시 에틸렌 발생량을 감소시키는 물질로 보고된 바와 같이(8) 사과와 $(10,13)$ 복숭아(17-19) 과실에 $\mathrm{AVG}$ 를 수확 전 처리하였을 때 수확시 과실의 경도가 높았고, 에틸렌 발생량도 감소한 결과를 보인 것과 같이 '포모사' 자두에서 도 동일한 결과를 나타내었다.

\section{상온저장 동안 과실품질 변화}

$\mathrm{AVG}$ 처리가 상온저장동안 '포모사' 과실의 경도와 에틸 렌 발생량의 변화에 미치는 영향을 보면 다음과 같다(Fig. 1). 무처리 과실의 경도는 수확시 $4.17 \mathrm{~N}$ 에서부터 상온저장 기간이 경과함에 따라 감소하였으며 특히 저장 8 일 이후부 터 경도가 급격히 감소하기 시작하여 12 일 이후부터는 2.00 $\mathrm{N}$ 이하로 감소되어 과실품질이 유지되지 않았다(Fig. 1A). 그러나 $\mathrm{AVG}$ 처리 과실들의 경도는 저장기간이 경과함에 따라 감소하는 경향을 보였지만 수확시 $6.29 \mathrm{~N}$ 에서 저장 24 일 이후에도 $4.00 \mathrm{~N}$ 이상을 보여 무처리 과실의 수확시와 유사한 매우 높은 경도를 유지하였다( $<<0.0001)$. 그리고 과실의 경도 변화와 밀접한 관련이 있는 에틸렌 발생량의 변화를 보면(Fig. 1B), 무처리 과실은 상온저장 8 일 이후부 터 급격히 증가되기 시작하여 저장 20 일 후에는 $90 \mu \mathrm{L} / \mathrm{kg} / \mathrm{h}$ 이상으로 최대치를 보였지만 AVG 처리 과실들은 처리시 기와 상관없이 저장 24 일 이후에도 $20 \mu \mathrm{L} / \mathrm{kg} / \mathrm{h}$ 이하로 낮은 에틸렌 발생량을 보여 과실의 상품성을 유지하는 결과를 보였다( $\mathrm{p}<0.0001)$. 앞에서도 언급하였듯이 $\mathrm{AVG}$ 는 사과 $(10,13)$ 와 배 $(15,16)$, 그리고 복숭아(17-21) 과실에 $\mathrm{AVG}$ 를 처리하였을 때 낮은 에틸렌 발생량과 높은 경도를 유지하는 효과를 보인 것은 $\mathrm{AVG}$ 가 과실에 적용되었을 때 에틸렌 생합성을 억제한 결과인 것으로 확인되었다. 따라서 '포모 사' 자두 과실은 관행재배 과실의 경우 수확후 상온
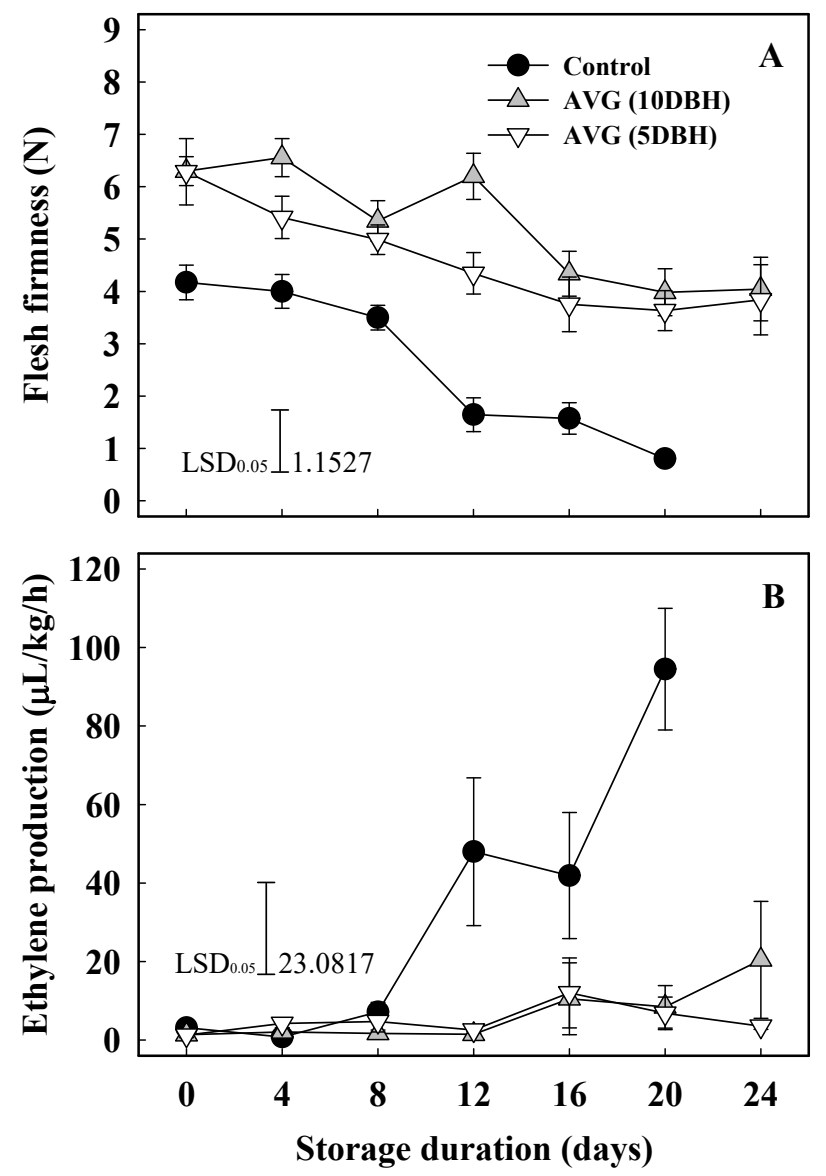

Fig. 1. Effects of AVG $(75 \mathrm{mg} / \mathrm{L})$ treatments on flesh firmness and ethylene production in 'Formosa' plum fruit during ambient temperature storage.

All value are expressed as Mean $\pm S E$ of triplicate determinations. DBH : days before harvest.

유통 한계기가 8 일 정도였으나, 수확 10 일전과 5 일전 $\mathrm{AVG}$ 처리 과실들은 상온저장시에도 경도가 높게 유지되어 상온 유통 한계기가 24일까지도 가능하다고 판단되었다. 
가용성 고형물 함량 변화를 보면 저장기간 동안 처리간 유효한 차이를 보이지 않았다(Fig. 2A). 산 함량의 변화를 보면(Fig. 2B) 무처리 과실은 수확시 $1.15 \%$ 였고 상온저장 12 일까지 $1.04 \%$ 를 유지하였으나 이후 급격히 감소되어 저 장 20 일 후 $0.87 \%$ 의 산 함량을 보였다. 그러나 수확 10 일전 과 5일전 $\mathrm{AVG}$ 처리 과실은 수확시 $1.15-1.16 \%$ 이던 산 함량 이 저장기간이 길어질수록 다소 감소하는 경향을 보였지만 저장 24 일 후에도 각각 $1.04 \%$ 와 $1.08 \%$ 로 산 함량이 여전히
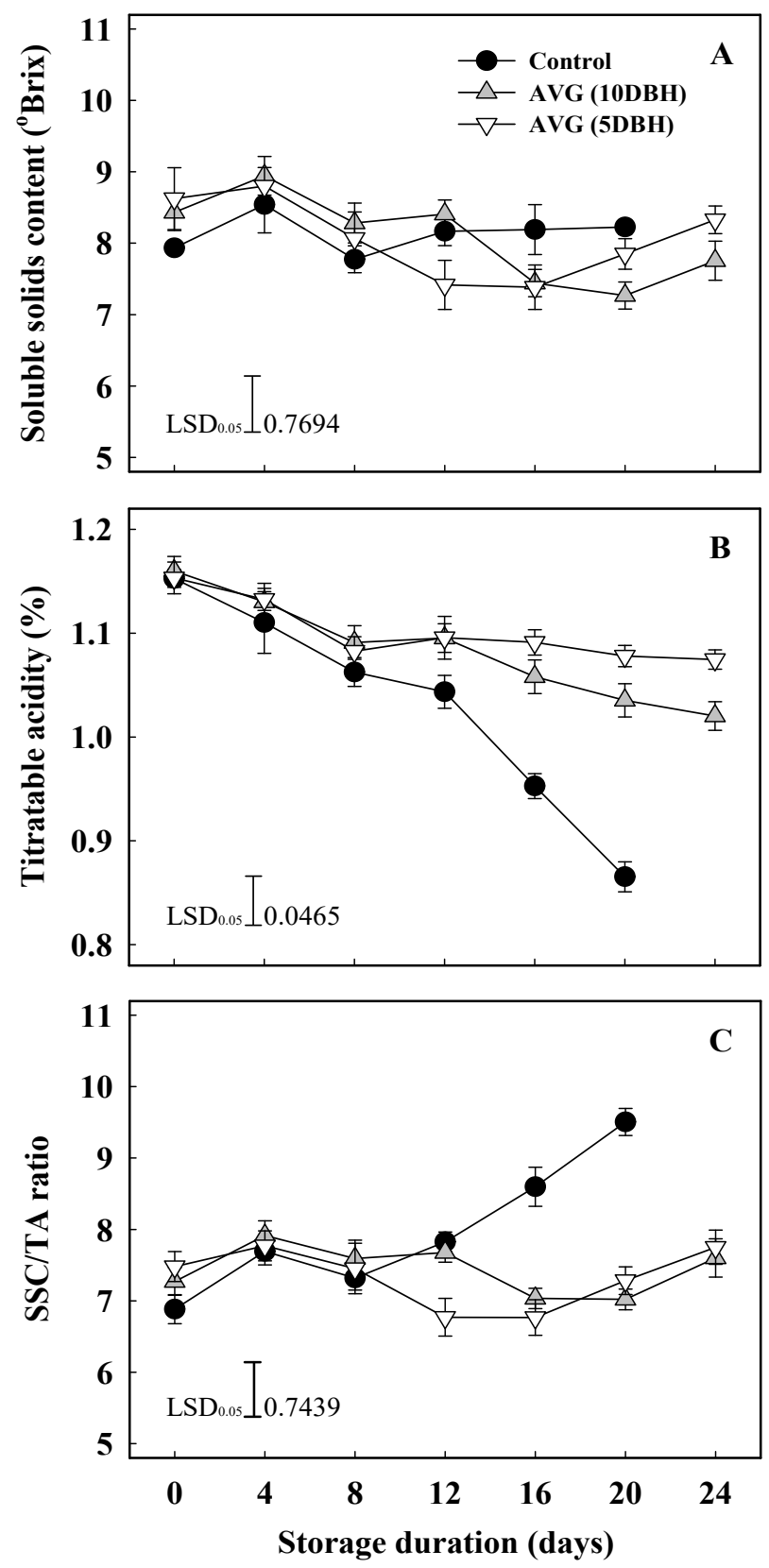

Fig. 2. Effects of AVG $(75 \mathrm{mg} / \mathrm{L})$ treatments on soluble solids content (SSC), titratable acidity (TA) and SSC/TA ratio in 'Formosa' plum fruit during ambient temperature storage.

All value are expressed as Mean $\pm \mathrm{SE}$ of triplicate determinations. DBH : days before harvest.
높게 유지되었다( $\mathrm{p}<0.0001)$. 이는 '산사'와 '쓰가루' 사과의 $\mathrm{AVG}$ 처리 효과를 보면 무처리 과실에 비하여 $\mathrm{AVG}$ 처리 과실에서 산 함량이 높은 결과를 보였고(10,13), 또한 ‘포모 사' 과실을 수확후 1-methylcyclopropene(1-MCP) 처리시 높 은 산 함량을 보였다고 하여(6) 본 연구에서도 에틸렌 제어 제 처리가 과실의 품질을 유지하는데 효과적임을 확인할 수 있었다. 가용성 고형물 함량(SSC)과 산 함량(TA)의 변화
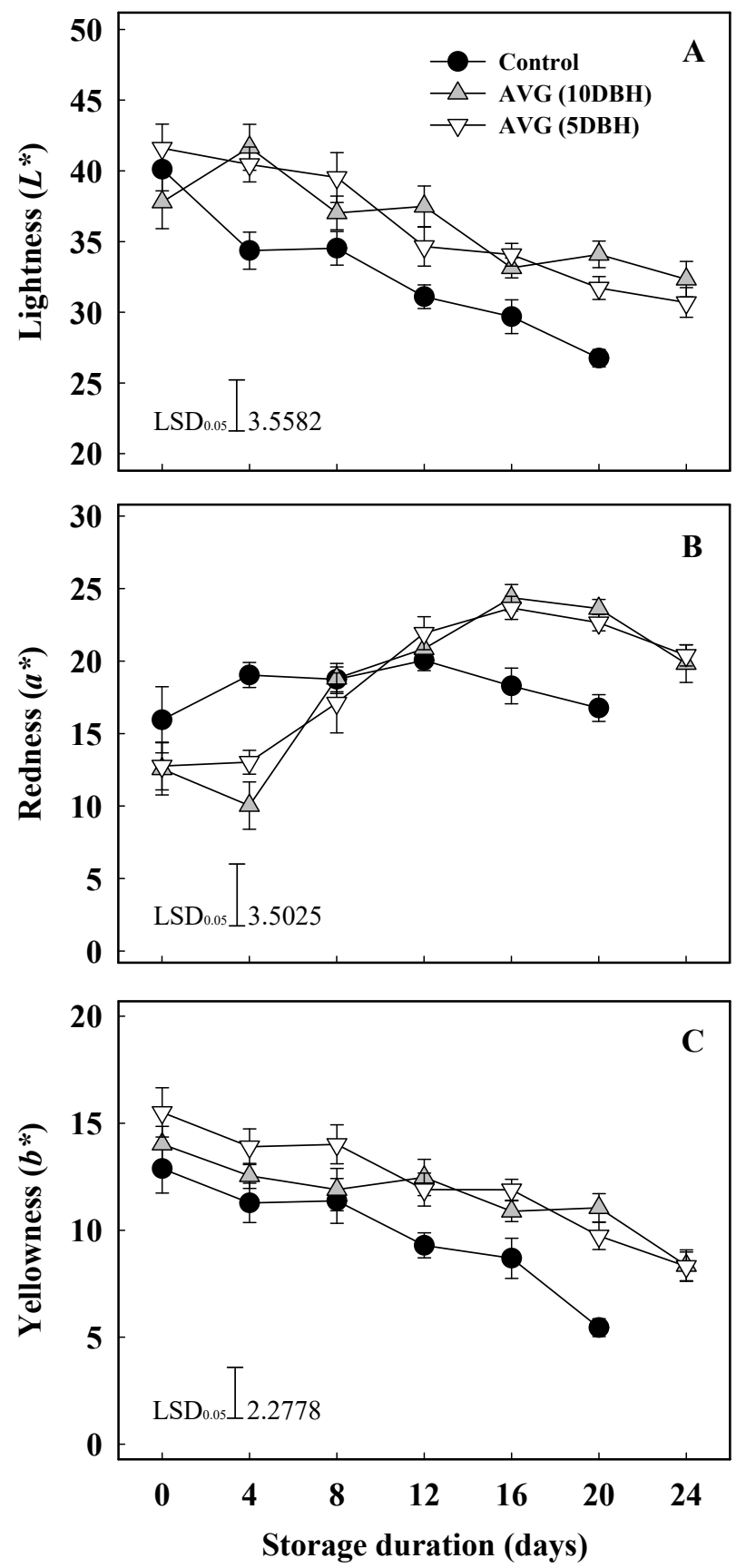

Fig. 3. Effects of AVG $(75 \mathrm{mg} / \mathrm{L})$ treatments on fruit peel color $\left(\mathrm{L}^{*}\right.$, $\left.a^{*}, b^{*}\right)$ in 'Formosa' plum fruit during ambient temperature storage.

All value are expressed as Mean $\pm \mathrm{SE}$ of triplicate determinations. DBH : days before harvest. 
에 따른 당산비(SSC/TA ratio)는 일 반적으로 과실의 맛과 품질을 평가하는 기준으로 이용되고 있다(22,23). AVG 처 리가 상온저장동안 '포모사' 자두의 당산비에 미치는 영향 을 보면 $\mathrm{Fig} . \mathrm{2C}^{\mathrm{C}}$ 와 같다. 무처리구의 경우 수확시 6.88 의 당산비를 보였으나 이후 저장기간동안 $\mathrm{SSC}$ 의 변화는 거의 없었던 반면에 $\mathrm{TA}$ 는 급격히 감소한 결과로 저장 20 일에는 당산비 9.51로(Fig. 2A,B) 품종 고유의 맛이 감소된 결과를 보였다. 그러나 AVG 처리 과실들은 당산비가 수확시와 저장 24일 이후에도 큰 변화가 없이 품종 고유의 맛이 유지 된 것을 확인할 수 있었다(p<0.0001). Minas 등(24)은 '조나 레드', '안젤리노' 자두에서 저장기간이 경과함에 따라 $1-\mathrm{MCP}$ 처리 과실은 당산비의 변화가 미미하였고, 반면 무 처리 과실은 당산비가 급격히 증가하여 이러한 결과는 에틸 렌과 호흡량이 증가되면서 유기산이 호흡기질로 소모된 결과로 해석하였다.

\section{상온저장 동안 과피 착색 변화}

저장기간 중 과피의 착색 변화는 다음과 같다(Fig. 3). 과피의 명도를 나타내는 $L^{*}$ 값은 모든 처리구에서 저장기간
동안 꾸준히 감소하는 경향을 보였으며 특히 무처리구의 경우 수확시 40.1 의 $L^{\star}$ 값이 저장 20 일 후 26.8 로 급격히 감소하였다(Fig. $3 \mathrm{~A}$ ). 그러나 수확 10 일전과 5일전 $\mathrm{AVG}$ 처리 과실들은 저장 24 일 후에도 각각 32.3 과 30.7 로 $L^{\star *}$ 값이 여전히 높게 유지되었다(p<0.05). 과피의 황색도를 나타내 는 $b^{\star}$ 값 역시 무처리구의 경우 수확시 12.9 에서 저장 20 일 후 5.4로 급격히 감소하였으나, 수확 10 일전과 5일전 $\mathrm{AVG}$

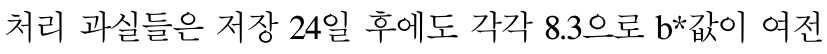
히 높게 유지되었다(p<0.01, Fig. 3C). 이는 저장기간이 경과 함에 따라 무처리구 과실의 경우 경도와 산 함량이 감소되 고 에틸렌 발생량이 급격히 증가하며 과실의 연화와 함께 수침현상이 진행되어 과피의 $L^{\star}$ 값과 $b^{\star}$ 값의 감소를 초래한 다 $(4,6,7)$ 는 보고와 동일한 결과를 보였다. 과피의 적색도를 나타내는 $a^{*}$ 값은 무처리 과실은 수확시 적색 색소의 발현 이 대부분 진행되어 저장기간동안 큰 변화가 발생하지 않았 지만, AVG 처리 과실은 수확시 $a^{\star}$ 값이 12.6 내외로 무처리 과실과는 통계적 유의성은 보이지 않았지만 착색이 다소 지연되는 결과를 보였다(Fig. 3B). 그러나 AVG 처리 과실은 저장기간 동안 $a^{\star}$ 값은 꾸준히 증가되어 저장 24 일 이후에

Table 2. Pearson correlation coefficient $(t)$ matrices among the responses of fruit quality attributes in 'Formosa' plums treated with AVG $(75 \mathrm{mg} / \mathrm{L})$ during ambient temperature storage

\begin{tabular}{|c|c|c|c|c|c|c|}
\hline & Lightness & Yellowness & Flesh firmness & $\mathrm{TA}$ & Ethylene production & Redness \\
\hline & \multicolumn{6}{|c|}{ Control } \\
\hline SSC & -0.157 & -0.114 & $-0.267^{* 1)}$ & 0.122 & 0.059 & $-0.250^{*}$ \\
\hline Lightness & & $0.788^{* *}$ & $0.837^{* *}$ & $0.699^{* *}$ & $-0.626^{* *}$ & 0.030 \\
\hline Yellowness & & & $0.690^{* *}$ & $0.588^{* *}$ & $-0.700^{* *}$ & -0.197 \\
\hline Flesh firmness & & & & $0.683^{* *}$ & $-0.718^{* *}$ & 0.053 \\
\hline $\mathrm{TA}$ & & & & & $-0.695^{* *}$ & -0.071 \\
\hline \multirow[t]{2}{*}{ Ethylene production } & & & & & & -0.188 \\
\hline & \multicolumn{6}{|c|}{ AVG (10DBH2) } \\
\hline SSC & $0.497^{* *}$ & $0.350^{* *}$ & $0.526^{* *}$ & $0.575^{* *}$ & -0.151 & $-0.599^{* *}$ \\
\hline Lightness & & $0.729^{* *}$ & $0.570^{* *}$ & $0.406^{* *}$ & $-0.508^{*}$ & $-0.582^{* *}$ \\
\hline Yellowness & & & $0.502^{* *}$ & $0.303^{*}$ & $-0.479^{*}$ & $-0.451^{* *}$ \\
\hline Flesh firmness & & & & $0.481^{* *}$ & $-0.563^{* *}$ & $-0.356^{* *}$ \\
\hline $\mathrm{TA}$ & & & & & -0.104 & $-0.498^{* *}$ \\
\hline \multirow[t]{2}{*}{ Ethylene production } & & & & & & 0.248 \\
\hline & \multicolumn{6}{|c|}{ AVG (5DBH) } \\
\hline SSC & $0.452^{* *}$ & $0.392^{* *}$ & $0.491^{* *}$ & $0.453^{* *}$ & $-0.477^{*}$ & $-0.563^{* *}$ \\
\hline Lightness & & $0.938^{* *}$ & $0.500^{* *}$ & $0.413^{* *}$ & -0.066 & $-0.796^{* *}$ \\
\hline Yellowness & & & $0.484^{* *}$ & $0.348^{* *}$ & -0.046 & $-0.656^{* *}$ \\
\hline Flesh firmness & & & & $0.368^{* *}$ & -0.265 & $-0.494^{* *}$ \\
\hline TA & & & & & -0.062 & $-0.480^{* *}$ \\
\hline Ethylene production & & & & & & 0.285 \\
\hline
\end{tabular}

\footnotetext{
${ }^{1)}$ Asterisks $\left({ }^{*}\right.$ or $\left.{ }^{* *}\right)$ indicate statistically significant correlations at $p<0.05$ or 0.01 , respectively.
}

${ }^{2}$ DBH: days before harvest date, which was 19 July, 2016. 
는 19.8-20.4로 착색이 진행되었다. 이러한 결과는 자두의 저장동안 숙성이 진행되면서 과피색 $a^{*}$ 값이 증가하게 되고 (3), 또한 '복숭아' 과실에서 AVG 처리시 과실의 성숙이 억제되면서 착색이 지연되었다고(20) 하였다. '포모사' 과 실에서도 AVG 처리가 수확시 과실의 착색 $\left(a^{*}\right.$ 값 $)$ 을 지연시 키는 경향을 보였지만 저장기간 중에 적색의 발현이 진행되 는 것을 확인할 수 있었다.

\section{상관관계 분석}

수확전 AVG 처리가 저장기간동안 과실품질 특성요인간 상관관계에 미치는 영향을 보면 다음과 같다(Table 2). 수확 전 AVG 처리가 저장기간중 과실의 품질을 평가하는 대표 적인 요인인 경도, 산 함량, 그리고 에틸렌 발생량 간에 상이한 상관관계를 보이고 있다. 경도와 산 함량은 무처리 구의 경우 에틸렌 발생량과 높은 부의 상관관계(경도 $r=-0.718^{* *}$, 산 함량 $\left.r=-0.695^{* *}\right)$ 를 보였으나, 수확 5 일전 $\mathrm{AVG}$ 처리구는 부의 상관관계(경도 $r=-0.265, r=-0.062$ )가 감소하였다. 에틸렌 발생량과 $\mathrm{L}^{*}$ 값의 상관관계 역시 무처 리구의 경우 높은 부의 상관관계 $\left(r=-0.626^{* *}\right)$ 를 보였으나 수확 10 일전과 5 일전 $\mathrm{AVG}$ 처리구는 부의 상관관계 $\left(t=-0.508^{*}, t=-0.066\right)$ 가 감소하였고, 에틸렌 발생량과 $b^{\star}$ 값 역시 동일한 결과를 나타내었다. 또한 경도와 $a^{\star}$ 값은 무처 리구의 경우 정의 상관관계(r=0.053)를 보였지만 $\mathrm{AVG}$ 처리 구들은 부의 상관관계 $\left(r=-0.356^{* *}, r=-0.494^{* *}\right)$ 를 나타내었 다. 이는 AVG는 ACC synthase의 활성억제를 통하여 에틸 렌 생합성을 억제 $(13,16,19)$ 함으로서 과실의 성숙과 연화를 억제하는 효과로 과실특성 요인간에 AVG 처리 유무에 따 른 상이한 상관관계를 보이는 것으로 판단되었다.

이상의 결과를 종합해 보면 '포모사' 자두에 수확 전 $\mathrm{AVG}$ 수체살포가 상온저장 동안 과실로부터 에틸렌 발생 량을 감소시키고 그에 따른 경도와 산 함량의 변화를 억제 시켜 과실의 품질을 유지하는데 효과적인 결과를 보였다. 따라서 수확 전 AVG 수체살포가 수확후 ‘포모사' 자두의 과실품질 변화를 억제하므로서 수확후 상온유통에 따른 보구력이 약한 단점을 보완할 수 있었고, 또한 상온유통 한계기를 연장할 수 있는 실용화기술로 판단되었다.

\section{요 약}

본 연구는 '포모사' 자두 과실에 수확전 aminoethoxyvinylglycine(AVG $75 \mathrm{mg} / \mathrm{L}$ )을 처리하였을 때 수확후 상온저장시 품질변화에 미치는 영향을 구명하고자 하였다. 저장기간 동안 과실의 경도는 무처리 과실의 경우 저장 12 일 이후 $2.00 \mathrm{~N}$ 이하로 감소되었으나, AVG 처리 과실들은 저장 20 일 후에도 $4.00 \mathrm{~N}$ 이상을 유지하였다. 에 틸렌 발생량은 무처리 과실의 경우 저장 12 일 후부터 증가
하기 시작하여 저장 20 일후 $90.0 \mu \mathrm{L} / \mathrm{kg} / \mathrm{h}$ 로 급격한 증가를 보였지만, AVG 처리 과실들은 저장 24일 이후에도 20.0 $\mu \mathrm{L} / \mathrm{kg} / \mathrm{h}$ 이하의 낮은 에틸렌 발생량을 보였다. 산 함량의 경우 무처리 과실은 수확시 $1.15 \%$ 에서 저장 20 일 후 $0.87 \%$ 로 감소하였으나, AVG 처리 과실들은 저장 24일 이후에도 1.04-1.08\%로 높게 유지되었다. 수확시 과피의 적색도 $\left(\mathrm{a}^{*}\right)$ 는 통계적 유의성은 보이지 않았지만 저장기간동안 AVG 처리 과실들에서 착색이 진행되었다. 따라서 '포모사' 자두 에 수확 전 $\mathrm{AVG}$ 처리는 상온저장 동안 과실의 에틸렌 발생 량을 감소시키고, 경도와 산 함량을 높게 유지시켜 과실의 품질을 유지하는데 효과적이라고 판단되었다.

\section{감사의 글}

이 논문은 2019학년도 경북대학교 국립대학육성사업 지 원비에 의하여 연구되었음.

\section{References}

1. Statistics Korea database (2018) Fruit cultivation area in Korea. http://kosis.kr/stat Html/statHtml.do Accessed 26 June 2018

2. Abdi N, Holford P, McGlasson WB, Mizrahi Y (1997) Ripening behaviour and responses to propylene in four cultivars of Japanese type plums. Postharvest Biol Technol, 12, 21-34

3. Cho MA, Hong YP, Choi SY, Jung DS, Lim BS, Park SJ, Lee SK (2011) The chilling injury development and quality characteristics of 'Ooishiwase' plums (Prunus salicina L.) according to ripening stages and cold storage temperature. Korean J Food Preserv, 18, 651-660

4. Dong L, Lurie S, Zhou HW (2002) Effect of 1-methylcyclopropene on ripening of 'Canino' apricots and 'Royal Zee' plums. Postharvest Biol Technol, 24, 135-145

5. Taylor MA, Rabe E, Jacobs G, Dodd MC (1995) Effect of harvest maturity on pectic substances, internal conductivity, soluble solids and gel breakdown in cold stored 'Songold' plums. Postharvest Biol Technol, 5, 285-294

6. Jung JH, Kim YC, Jung SK (2010) Fruit quality of 1-methylcyclopropene treated 'Formosa' plum on the shelf life at ambient temperature. Kor J Hortic Sci Technol, 28, 429-433

7. Menniti AM, Donati I, Gregori R (2006) Responses of 
1-MCP application in plums stored under air and controlled atmospheres. Postharvest Biol Technol, 39, 243-246

8. Boller T, Robert CH, Kende H (1979) Assay for and enzymatic formation of an ethylene precursor, 1-aminocyclopropane-1-carboxylic acid. Planta, 145, 293-303

9. Chun JP, Park MS, Hwang YS, Lee JC (1997) Effect of AVG on harvest drop and fruit quality in 'Tsugaru' apples. J Korean Soc Hortic Sci, 38, 147-152

10. Park MY, Kwon HJ, Kang IK, Byun JK (1999) Effects of AVG application on harvest time extension and storability improvement in 'Tsugaru' apples. J Korean Soc Hortic Sci, 40, 577-580

11. Park JY, Kim KO, Yoo JG, Win NM, Lee JW, Choung MG, Jung HY, Kang IK (2016) Effects of aminoethoxyvinylglycine (AVG) and 1-methylcyclopropene (1-MCP) treatments on fruit quality attributes in cold-stored 'Jonathan' apples. Korean J Food Preserv, 23, 453-458

12. Argenta LC, Vieira MJ, Krammes JG, Petri L, Basso C (2006) AVG and 1-MCP effects on maturity and quality of apple fruit at harvest and after storage. Acta Hortic, 727, 495-504

13. Kang IK, Park MY, Byun JK (2002) Effects of the AVG application on preharvest fruit drop by typhoon, harvest date extension and fruit quality improvement in 'Sansa' apple fruits. Hortic Environ Biotechnol, 43, 191-194

14. Yuan R, Li J (2008) Effect of sprayable 1-MCP, AVG, and NAA on ethylene biosynthesis, preharvest fruit drop, fruit maturity, and quality of 'Delicious' apples. HortScience, 43, 1454-1460

15. Khan ZU, Ohara H, Ohkawa K, Matsui H (2002) Effect of aminoethoxyvinylglycine (AVG) on ethylene evolution and fruit quality of Japanese pears at harvest stage. Acta Hortic, 587, 533-537
16. Lee UY, Oh KS, Choi JH, Ahn YJ, Chun JP (2014) Changes of fruit quality and reduction of physiological disorders during shelf-life in early-season pear (Pyrus pyrifolia Nakai) fruits treated with aminoethoxyvinylglycine. Korean J Hortic Sci Technol, 32, 193-201

17. Byers RE (1997) Peach and nectarine fruit softening following aminoethoxyvinylglycine sprays and dips. HortScience, 32, 86-88

18. Bregoli AM, Scaramagli S, Costa G, Sabatini E, Ziosi V, Biondi S, Torrigiani P (2002) Peach (Prunus persica) fruit ripening: aminoethoxyvinylglycine (AVG) and exogenous polyamines affect ethylene emission and flesh firmness. Physiol Plant, 114, 472-481

19. Wang MH, Lee UY, Oh KS, Lee EG, Ahn YJ, Hwang YS, Chun JP (2012) Effect of preharvest aminoethoxyvinylglycine spraying time on fruit quality of 'Nagasawa Hakuho' peach (Prunus persica Batsch) during shelf-life. Kor J of Agri Sci, 39, 503-509

20. Ctinbas M, Butar S, Onursal CE, Koyuncu MA (2012) The effects of pre-harvest ReTain [aminoethoxyvinylglycine (AVG)] application on quality change of 'Monroe' peach during normal and controlled atmosphere storage. Sci Hortic, 147, 1-7

21. Kim IS, Choi CD, Lee HJ, Byun JK (2004) Effects of aminoethoxyvinylglycine on preharvest drop and fruit quality of 'Mibaekdo' peaches. Acta Hortic, 653, 173-178

22. Robertson JA, Meredith FI, Scorza R (1989) Physical, chemical and sensory evaluation of high and low quality peaches. Acta Hortic, 254, 155-159.

23. Bassi D, Selli R (1990) Evaluation of fruit quality in peach and apricot. Adv Hortic Sci, 4, 107-112

24. Minas IS, Forcada CF, Dangl GS, Gradziel TM, Dandekar AM, Crisosto CH (2015) Discovery of non-climacteric and suppressed climacteric bud sport mutations originating from a climacteric Japanese plum cultivar (Prunus salicina Lindl.). Front Plant Sci, 6, 316 